Preventive Care in Nursing and Midwifery Journal

2019; 9(1): 12-21

\title{
A Survey on the readiness of e-teaching among Faculty Members of Zanjan University of Medical Sciences in 2014
}

\author{
Maleki $A^{1} \stackrel{\text { Moosavi Sahebalzamani }}{S^{2 *}}{ }^{*}$, Faghihzadeh $S^{3}$, Sepehri nia $M^{4}$ (i) \\ ${ }^{1} \mathrm{PhD}$ in maternal and child health, Assistant Professor, Social Determinants of Health Research Center, Department of Midwifery, School of Nursing \\ and Midwifery, Zanjan University of Medical Sciences, Zanjan, Iran \\ ${ }^{* 2}$ Department of Midwifery, School of Nursing and Midwifery, Zanjan University of Medical Sciences, Zanjan, Iran \\ ${ }^{3}$ Professor of Biostatistics, Zanjan Social Dept. of Health Research Center, Zanjan University of Medical Sciences, Zanjan, Iran \\ ${ }^{4}$ Department of pediatric Nursing, School of Nursing and Midwifery, Zanjan University of Medical Sciences, Zanjan, Iran
}

*Corresponding Author: Department of Midwifery, School of Nursing and Midwifery, Zanjan University of Medical Sciences, Zanjan, Iran

Email: moosavis@zums.ac.ir

Received: 15 Dec $2019 \quad$ Accepted: 16 March 2020

\begin{abstract}
Background: Application of technology for education accounts for an important aspect of expansion of the information technology in the present century.

Objectives: This study aims to examine the degree of readiness of the faculty member of Zanjan University of Medical Sciences for e-Teaching.

Methods: This descriptive-cross-sectional study focused on the degree of readiness of 70 faculty member of Zanjan University of Medical Sciences in 2014. It followed the simple randomized sampling method. The readiness of faculty member was assessed from five dimensions, including organizational support, perceived value, and time commitment, working skill, access to computer, internet and attitude towards e-Teaching, using a standard questionnaire. The data were analyzed using descriptive statistics indices, Pearson correlation coefficient and Logistic Regression Model at 95\% confidence interval.

Results: The university faculty member were in adequate level of readiness in terms of organizational support (46.4\%), positive attitude towards e-Teaching (49.3\%); the skill of work with computer (49.3\%), time commitment (44.9\%), access to computer $(49.3 \%)$ and positive perceived value $(45.6 \%)$. The predictive variables of the university faculty member' readiness were appropriate in terms of organizational support, access to computer and in term of, perceived value, age and gender of the university faculty member in term of, perceived time obligation, skill in work with computer and organizational support.

Conclusion: The results showed that readiness of the the faculty member of Zanjan University of Medical Sciences for e-Teaching was in a relatively appropriate level. Expanson of the technological infrastructure, holding empowerment workshops in order for improvement of the required skill and changing attitude of the university faculty member for e-Teaching are suggested.
\end{abstract}

\section{Keywords: readiness, faculty member of University of Medical Sciences, e-Learning}

\section{Introduction}

Using technology for education marks an important aspect of expansion of information technology and communications in present century, opening up new horizons towards universities [1]. Compared to the past, the medical science faculty member today face enormous challenges in teaching the medical students. Over recent years, abundant efforts have been made for replacing the Stereotype and traditional methods with new and genuine methods based on the personal and social needs of students [2].

Studies have shown that using technology in education will cut educational expenditures, save time, raise opportunities of learning and teaching, incrase educational success and make it possible to have swift access to information [3]. 
eTeaching covers a wide scale and can be webbased, computer assisted learning, digital-based like tablet or mobile, which are at the disposal of the service receivers (school and college students) [4].

The key to implementation of the e-Teaching systems in organizations is preparing necessary conditions in various dimensions, which are regarded as readiness for e-Teaching [1]. The requisite for e-Teaching is having various dimensions of readiness in terms of technical infrastructure, cultural readiness, financial support, human sources and so on [5]. This is while assessment of the degree of readiness allows the officials to take necessary and due policies and measures for development of projects through partnership of all the beneficiary groups [6].

To this end, some universities of medical sciences assess their degree of readiness for eTeaching from various aspects. The results of such studies in Alborz University of Medical Sciences shows that the university is in favorable level in terms of organizational, cultural andfinancial support as well as technical infrastructures and personal readiness [7].

Furthermore, the readiness of the university faculty member of universitis of medical sciences in western part of the country in terms of attitude, knowledge and the skill of work with computer and internet show that majority of the faculty member have positive attidue and enjoy average lavel of knowledge and skill for the purpose [8].

Of course, studies in other universities have shown contradictory results $[3,9]$.

Deterrent obstances and factors, including personal factors, organizational attitude and support are mentioned as influential in materialization of e-Teaching [10]. Therefore, organizational support for internet-based education consists of technical and financial support and educational planning. While providing necessary equipment and resources for the web-based education, financial support can be in the form of receipt of expenditures and financial rewards, thus further motivating the faculty member to implement the program [11]. The degree of profitability with perceived value, attitude, skill and self-efficiency in using computer can be as influential as organization support, making members of the board of instructor inclined to use the e-Teaching systems $[12,13]$. By perceived profitability, the researcher means the degree of the person's belief in using a special system which would improve his/her professional conduct. Personal understanding of the profitability of a system is affected by the reality that $\mathrm{s} / \mathrm{he}$ perceives a system application is so simple. By perceived obstacles the researcher means any factor, including the organization and social factors, specifications of a computer system such as the type of hardware and software and the quality of education and other people's help in using the computer systems that negatively affect the person's mental attitude towards using the information technology [14].

Despite diversity of factors affecting admission and use of technology by the people in charge of teaching, identification of the amount of readiness and the influential factors in different universities is of special importance.

Meanwhile, as the key part of the learning procedure, faculty member should be well ready in terms of belief, attitude, knowledge, skill, access and degree of using e-Teaching. Since implementation of the e-Teaching program is one of the policies of Zanjan University of Medical Sciences, successful implementation of eTeaching in the university, evaluation of the degree of readiness of the faculty member from different dimensions seems so necessary. Furthermore, regarding inavailability of similar studies, this study was conducted in 2014 with the purpose of determining the degree of readiness of the faculty member of Zanjan University of Medical Sciences in e-Teaching.

\section{Methods}

This study is descriptive-cross sectional in nature, conducted in 2014 with the purpose to survey the degree of readiness of the faculty member of Zanjan University of Medical Sciences for e-Teaching. The population undergoing this research were all the faculty member of Zanjan University of Medical Sciences, who were asked to submit their informed consent after undergoing the sampling procedure. The criteria for their selection was teaching in Zanjan University of Medical Sciences having a position in the board of academic-education faculty member and teaching for at least one semester. The participants were selected using simple 
randomized sampling method. The sampel size was on pilot study, taking the least error of $\mathrm{X}^{-}$ 1.10 and variable of 5 for a group of 70 members as the criteria.

The data were studied using the Demographic Information Questionnaire, consisting of (age, Gender, history of teaching, scientific position, the position of service) and readiness of the faculty member on five dimensions, including the perceived organizational support (seven questions) and the perceived value on e-Teaching (14 questions), perceived time commitment (three questions), the skill of work with computer (15 questions) and access to computer and internet (four questions). The questionnaire of the faculty member' readiness by Gasaymeh et al. was designed and underwent psychometric procedure [11]. This study confirmed the content validity of the questionnaires after translation and retranslation, using the perceptions of the experts, and their reliability, estimated by cronbach In order for reliability of the questionnaire, modified using Hashemi et al. questionnaire (2011) as model and the views of the content experts for revision, will be estimated, using Cronbach's alpha formula for organizational support $(0.78)$ and the perceived value to e-Learning (0.88), access (0.79), time commitment (0.81), and skill (0.86). Furthermore, to assess the attitude of faculty member Mishra's E-Learning Attitude Scale questionnaire was used, consisting of 22 items. The scoring of the questionnaire items was on the five-point Likert scale. The reliability coefficient of the questionnaire on internal studies was 0.71 and on external studies was 0.81 . $[15,16]$. This study confirmed the re-reliability of Mishra's E-Learning Attitude Scale questionnaire with 0.90 coefficient. To investigate the readiness of the faculty member in each dimensions, this study used mid cut point, taking the score higher than the mean as sign of readiness.

To describe the data, this study used frequency distribution, mean and dispersion indices, while benefitting from Pearson Correlaton Coefficient and Backward Logistic Regression Model at 95\% level of significance. Therefore, all the demographic variables and various dimensions of readiness for e-Teaching were entered into the model and using backward method, each variable was derived out of the model and the predictive variables were gained in the final model.

\section{Results}

The results provided in this section are gained through analysis of the data relating to 69 university faculty member. The difference in distribution of data is mentioned in each table, while pointing to the number on the sample mortality.

Table 1 shows that majority of the participant faculty member were male $(73.5 \%)$, falling within the age group of $30-49$ years $(36.2 \%)$ with the teaching experience of less than four years $(39.7 \%)$. Their position was associate professor $(68.7 \%)$ and were engaged in the faculty of medicine $(37.7 \%)$.

The mean age of the faculty member was $41.13 \pm 8.72$. Moreover, the mean score of the attitude of faculty member to e-Teaching was $73.04 \pm 11.02$, organizational support was $20.15 \pm 4.16$, perceived value of e-Teaching $45.38 \pm 8.73$, access to computer and internet was $15.52 \pm 3.72$, time commitment was $8.85 \pm 2.92$, and skill of work with computer and internet was $47.91 \pm 9.20$. The range of the gained score in attitude was 29-102, organizational support 9-31, the perceived value 16-70, access to computer 520 , time commitment 3-15 and skill of work with computer 27-70. 
Table 1: Frequency Distribution and Percentage of the Demographic Information of the Faculty member $(n=69)$

\begin{tabular}{|c|c|c|c|c|}
\hline \multicolumn{2}{|c|}{ Variable } & Frequency & Percent & Total \\
\hline \multirow{2}{*}{ Gender } & Male & 50 & 73.5 & \multirow{2}{*}{68} \\
\hline & Female & 18 & 26.5 & \\
\hline \multirow{4}{*}{ Age (in year) } & $30>$ & 9 & 13 & \multirow{4}{*}{69} \\
\hline & $30-39$ & 25 & 36.2 & \\
\hline & $40-49$ & 25 & 36.2 & \\
\hline & $50<$ & 10 & 14.5 & \\
\hline \multirow{5}{*}{$\begin{array}{c}\text { Background of } \\
\text { Teaching (in } \\
\text { year) }\end{array}$} & $5>$ & 25 & 39.7 & \multirow{5}{*}{ *63 } \\
\hline & $5-9$ & 11 & 17.5 & \\
\hline & $10-14$ & 6 & 9.5 & \\
\hline & $15-19$ & 12 & 19 & \\
\hline & $20<$ & 9 & 14.3 & \\
\hline \multirow{4}{*}{$\begin{array}{l}\text { Scientific } \\
\text { Position }\end{array}$} & Instructor & 14 & 20.9 & \multirow{4}{*}{${ }^{*} 67$} \\
\hline & Associate Professor & 46 & 68.7 & \\
\hline & Assistant Professor & 6 & 9 & \\
\hline & Full Professor & 1 & 1.5 & \\
\hline \multirow{5}{*}{$\begin{array}{c}\text { The Faculty of } \\
\text { Service }\end{array}$} & Health & 15 & 21.7 & \multirow{5}{*}{69} \\
\hline & Nursing & 11 & 15.9 & \\
\hline & Medicine & 26 & 37.7 & \\
\hline & Pharmacology & 12 & 17.4 & \\
\hline & Dentisry & 5 & 5.2 & \\
\hline
\end{tabular}

\section{*Sample mortality}

Table 2 shows that the adequate readiness in terms of organizational support was $46.4 \%$, of positive attitude was $49.3 \%$, of the skill of work with computer was $49.3 \%$, of time commitment was $44.9 \%$, of access to computer was $49.3 \%$ and of the perceived value was $45.6 \%$.

\section{Table 2: Percentage and Frequency of the Domains of Faculty member'} Readiness for e-Teaching Based on the Mid Cut Point

\begin{tabular}{|c|c|c|c|}
\hline Variable & Mid Cut Point & Percent & Frequency \\
\hline \multirow{2}{*}{ Attitude } & Negative & 50.7 & 35 \\
\hline & Positive & 49.3 & 34 \\
\hline \multirow{2}{*}{ Skill } & Inadequate & 50.7 & 35 \\
\hline & Adequate & 49.3 & 34 \\
\hline \multirow{2}{*}{$\begin{array}{c}\text { Time } \\
\text { Commitment }\end{array}$} & Inadequate & 55.1 & 38 \\
\hline & Adequate & 44.9 & 31 \\
\hline \multirow{2}{*}{ Access } & Inadequate & 50.7 & 35 \\
\hline & Adequate & 49.3 & 34 \\
\hline \multirow{2}{*}{$\begin{array}{c}\text { Organizational } \\
\text { Support }\end{array}$} & Inadequate & 53.6 & 37 \\
\hline & Adequate & 46.4 & 32 \\
\hline \multirow{2}{*}{ Perceived Value } & Negative & 54.4 & 37 \\
\hline & Positive & 45.6 & $* 31$ \\
\hline
\end{tabular}

\section{*Sample mortality}

Table 3 also shows that readiness of the faculty member in terms of the perceived organizational support had positive and significant correlation with time commitment $(\mathrm{r}=0.24)$, access to computer $(\mathrm{r}=0.44)$ and age $(\mathrm{r}=0.24)$.
Readiness in terms of the domain of perceived value had positive and significant correlation with attitude $(\mathrm{r}=0.7)$ and the skill of work with computer $(\mathrm{r}=0.34)$.

Readiness in terms of the skill of work with computer had direct correlation with access to 
computer $(\mathrm{r}=0.28)$, while having reversed and significant correlation with age $(r=-0.36)$ and background of teaching ( $\mathrm{r}=-0.36)$.

Readiness in terms of time commitment had direct correlation with skill $(\mathrm{r}=0.31)$ and access to computer $(\mathrm{r}=0.43)$, while had reversed and significant correlation with background of teaching $(\mathrm{r}=-0.36)$.

In terms of access to computer, readiness had positive and significant correlation with time commitment $(\mathrm{r}=0.43)$ and the skill of work with computer $(\mathrm{r}=0.28)$.

Table 3: Correlation of the Domains of Faculty member' Readiness for e-Learning and Demographic Variables

\begin{tabular}{|c|c|c|c|c|c|c|c|c|}
\hline & $\begin{array}{l}\text { Organizational } \\
\text { Support }\end{array}$ & $\begin{array}{c}\text { Perceived } \\
\text { Value }\end{array}$ & Attitude & $\begin{array}{c}\text { Time } \\
\text { Commitment }\end{array}$ & $\begin{array}{c}\text { Skill of } \\
\text { Work with } \\
\text { Computer }\end{array}$ & $\begin{array}{l}\text { Access to } \\
\text { Computer }\end{array}$ & Age & $\begin{array}{c}\text { Teaching } \\
\text { Experience }\end{array}$ \\
\hline $\begin{array}{c}\text { Organizational } \\
\text { support }\end{array}$ & 1 & & & & & & & \\
\hline $\begin{array}{c}\text { Perceived } \\
\text { Value }\end{array}$ & -0.07 & 1 & & & & & & \\
\hline Attitude & -0.01 & * 0.7 & 1 & & & & & \\
\hline $\begin{array}{c}\text { Time } \\
\text { Commitment } \\
\end{array}$ & ${ }^{*} 0.24$ & 0.007 & 0.13 & 1 & & & & \\
\hline $\begin{array}{c}\text { Skill of Work } \\
\text { with Computer }\end{array}$ & -0.05 & ${ }^{*} 0.34$ & ${ }^{*} 0.23$ & ${ }^{*} 0.31$ & 1 & & & \\
\hline $\begin{array}{l}\text { Access to } \\
\text { Computer }\end{array}$ & ${ }^{*} 0.44$ & -0.15 & -0.02 & ${ }^{*} 0.43$ & ${ }^{*} 0.28$ & 1 & & \\
\hline Age & 0.24 & 0.006 & -0.004 & -0.18 & ${ }^{3}-0.36$ & -0.09 & 1 & \\
\hline $\begin{array}{c}\text { Teaching } \\
\text { Experience }\end{array}$ & 0.13 & 0.009 & -0.007 & ${ }^{*}-0.26$ & ${ }^{*}-0.36$ & -0.16 & ${ }^{*} 0.87$ & 1 \\
\hline
\end{tabular}

\section{"Less than 0.05 level of significance}

Table 4 shows that the predictive variables of readiness were positive in terms of organizational support and access to computer and internet to the extent that those having access to computer had 1.26 times more chance of having favorable organizational support compared to others.

The predictive variables of readiness were age, gender and attitude from the standpoint of the positive perceived value to the extent that the variable values for those of higher age with female gender and positive attitude were 1.16, 11.6 and 1.28 times more than others.

The predictive variables of readiness substantiated perceived time commitment, the skill of work with computer and organizational support.
Therefore, the chance of having adequate time commitment was 1.08 and 1.19 times higher for those having the required skill and organization support, respectively.

The predictive variables of readiness in terms of the skill of work with computer included the teaching experience, access to computer and perceived value to the extent that the chance of the people with less teaching experience, adequate access and positive perceived value in having high skill was $0.88,1.24$ and 1.09 times more.

Moreover, the chance of women's positive attitude was 13.6 times and positive perceived value was 1.5 times that of other people. 
Table 4: Predictive Variables of Organizational Support, Perceived Value, Faculty member' Perceived Time Commitment and Attitude

\begin{tabular}{cccccc}
\hline Variable & $\begin{array}{c}\text { Predictive } \\
\text { Variables }\end{array}$ & B & OR & CI 95\% & P Value \\
\hline $\begin{array}{c}\text { Organizational } \\
\text { Support }\end{array}$ & $\begin{array}{c}\text { Access to } \\
\text { Computer }\end{array}$ & 0.23 & 1.26 & $1.06-1.50$ & 0.008 \\
\hline \multirow{2}{*}{ Attitude } & Gender & 2.61 & 13.61 & $1.56-118.92$ & 0.01 \\
& Perceived Value & 41.0 & 1.52 & $1.24-1.82$ & 0.0001 \\
\hline \multirow{3}{*}{ Time Commitment } & Skill & 0.08 & 1.08 & $1.01-1.16$ & 0.01 \\
& $\begin{array}{c}\text { Organizational } \\
\text { Support }\end{array}$ & 0.18 & 1.19 & $1.04-1.37$ & 0.01 \\
\hline \multirow{3}{*}{ Skill } & $\begin{array}{c}\text { Teaching } \\
\text { Experience }\end{array}$ & -0.12 & 0.88 & $0.81-0.95$ & 0.003 \\
& Access & 0.21 & 1.24 & $1.02-1.50$ & 0.02 \\
\cline { 2 - 6 } & Perceived Value & 0.08 & 1.09 & $1.00-1.19$ & 0.04 \\
\cline { 2 - 6 } & Skill & 0.11 & 1.12 & $1.03-1.22$ & 0.004 \\
\cline { 2 - 5 } Access & Perceived Value & 0.15 & 0.85 & $0.76-0.96$ & 0.01 \\
& Attitude & 0.09 & 1.09 & $1.00-1.18$ & 0.03 \\
\hline \multirow{3}{*}{ Perceived Value } & Attitude & 0.25 & 1.28 & $1.11-1.49$ & 0.001 \\
& Age & 0.15 & 1.16 & $1.02-1.31$ & 0.01 \\
& Gender & 2.45 & 11.60 & $1.22-110.17$ \\
\hline
\end{tabular}

*After controlling effect of other variables in backward method

\section{Discussion}

The results of this study showed that readiness of the faculty member of Zanjan University of Medical Sciences for e-Teaching is in relatively appropriate condition from the dimensions of organizational support, the skill of work with the computer, time commitment, and access to computer, perceived value and positive attitude towards e-Teaching. The results of this study are not consistent with those of Darab et al. (2010), Zamani et al. (2010), Rezaei-Rad (2012) and Sheikhian et al. (2014) in certain aspects $(5,17$ 19). The reason for the inconsistency can be the time span when this study took place in 2010 . Sheikhian et al. (2014) in Lorestan University of Medical Sciences reported that this university is not well prepared for the purpose for poor educational-technical experience as well as from the standpoints of culture, equipment, communication network, manpower, management, educational policies, security and logistics [19]. Results of the afore-mentioned studies do not go with those of this study; of course, this study lacks any investigation into readiness in terms of the educational and cultural policies. Darabi et al. (2013) and Dehqan et al. (2015) offered similar findings and indicated that Qazvin and Alborz universities of medical sciences are well ready to receive and embark on development of the e-Teaching system [7,20]. The said results show that although readiness of university faculty member in certain universities of medical sciences is relatively in an appropriate level, there are more steps remaining to material e-Teaching in the universities in line with other universitis of the Ministry of Science, Research and Technology, including Sharif University of Technology, which is the pioneer in virtual education.

Results of this study showed that degree of organizational support for launching e-Teaching was almost $47 \%$ the adequate level, not consistent with findings of a study by Bakhshi et al. (2016) [21]. The shortcomings caused by technical, educational and administrative support caused restrictions in readiness of the faculty member as one of the major indices for readiness of the learners to participate in e-Learning [22,23]. Therefore, preparing the ground for implementation of the new educational technology, necessary technical facilities, financial support for the web-based educational projects and preparing the web-based technicaleducational skill could be taken as one of the policies for encouragement of the directors of universities in this field. 
Resutls of this study showed that the perceived value by faculty member to set up eTeaching was 46 percent positive to set up eTeaching system. The results are in agreement with a study by Mehrdad et al. (2015) to the extent that the degree of satisfaction of the faculty member with implementation of the virtual teaching was close to $44 \%$ and the mean perceived value $11.35 \pm 2.76$ [24]. The perceived value e-Teaching serves as the nucleus of persistant ideology, predictor of the degree of using the systems [12]. To successfully implement technology in an organization, one should pay attention to the background factors like organizational guidelines and the supportive structors for improvement of the attitude of staff towards using technology as well [10]. Time commitment or norm are as import as the perceived value for accepting the e-Teaching. This study showed that almost 45 percent of the faculty member had favorable time commitment. Time or norm commitment has something to do with obligation and accountability of the person towards organization [25]. This study showed that organizational support had positive and significant correltion with time commitment, access to computer and age, while time commitment had direct and linear correlation with degree of skill and access to computer, having reversed and significant relation with teaching experience. Relationship between organizational support and organization commitment has been emphasized in different studies, which fall in line with findings of this study [26,30]. Arshadi (2011), Panaccio and Vandenberghe (2009), DeConinck and Johnson (2009), Shakerinia and Davoodi (2010) and Poor-Soltani and Zarandi (2016) came up with similar results [26,30]. This study showed that inaccess to internet and computer was unfavorable in $50.7 \%$ of cases, going in line with study of Darabi et al. (2013). Lack of high wide band and/or lack of access to the educational management networks in proportion to needs of university were the most important factors for lack of access in using the e-Teaching, which should be considered by the university directors [31].

Ertmer believes that faculty member usually prefer a method for teaching to studies that they had experienced it themselves. Therefore, changing the traditional method into electronic method will not be successful unless the board of faculty member are empowered for the purpose. To this end the high level of literarcy on using the internet will increase the faculty member' selfconfidence, making them inclined to accept this new method of teaching [32]. Therefore, holding workshops for faculty member' familiarity with the Learning Management Systems, engagement with students through email, using educational websites and designing educational weblogs are recommended. In the same vein, Bahadorani and Yamani concluded that despite having positive attitude, major percentage of the faculty member lack required knowledge and skill for the purpose. Therefore, it is necessary to adopt measures to upgrade knowledge and function of the members of the university board of faculty member in order for optimal use of computer and internet [33].

Gasaymeh proved that the faculty member' positive attitude showed positive correlation with four variables of the degree of the faculty member' access to internet, time commitment, the computer and internet skills, the perceived value of education, being in negative correlation with the organizational support [11]. They are in line with the findings of this study. Of course, it should be noted that the attitudes and feelings of people have more precise relation with other behavioral and attitudinal variables that similar ground and framework is investigated [26].

Though internal (personal and attitutdinal) factors are in turn accounted for the primary and fundamental deterrents to the faculty member' participation in the virtual teaching, it can be justified that had it not been for the required external and organizational support for the faculty member' participation, the internal deterrent factors might have less affected their participation [10].

Therefore, increased support of the senior management of organization for the eLearnign and formation of a team of key directors and staff for expansion of e-Learning, support for the said team by senior directors of the organization and efforts for enagement of the team with other staff are suggested [7]. ETeaching is a newly emerged industry of educational and e-Learning technology in Iran. Therefore, Iranian educational centers and institutions, especially universities of medical sciences, are required to use a pattern in proportion to the country's educational and cultural structure to design e-Teaching 
environments based on the international standards [34].

This study's data were collected through the selfreport questionnaire, which is one of the limitations of this research. Furthermore, this study failes to consider the readiness of the faculty member in certain domains like the experience of e-Learning, which should be taken into consideration in generalizing the outcome of this research.

\section{Acknowledgments}

The permission for this research was received from the Education Department of Zanjan University of Medical Sciences and was conducted with the university's financial support. The research project 19.3-3.1467, coded A- 11344-3, was approved by the Research Information Management System with the ethics code of ZUMS.REC.1392.110.

Hereby, the researchers appreciate the faculty member of Zanjan University of Medical Sciences for helping them to conduct this research.

\section{Conflict of interest}

The authors of this article declare that there is noconflict of interest in writing this article.

\section{References}

1. Borotis S, Poulymenakou A. E-learning readiness components: Key issues to consider before adopting e-learning interventions. E-Learn: World Conference on E-Learning in Corporate, Government, Healthcare, and Higher Education; 2004: Association for the Advancement of Computing in Education (AACE).

2. Selwyn N. The use of computer technology in university teaching and learning: a critical perspective. J Comput Assist Lear. 2007; 23(2): 83-94.

3. Rokh Afruz D, Sayadi N, Hakim A. Investigating awareness of faculty members of nursing college in electronic teaching area.Educ Develop Jundishapur. 2012; 3(4): 30-38. [In Persian]

4. Chatti MA, Jarke M, Frosch-Wilke D. The future of e-learning: a shift to knowledge networking and social software. Int $\mathbf{J}$ Knowl Learn. 2007; 3(4-5): 404-20.

5. Darab B. Designing E-readiness Assessment Model of Universities in Iran. [dissertation].
Tehran: Information Technology Faculty, Engineering, Tarbiat Modarres University. 2009. [In Persian]

6. Kaur K, Zoraini Wati A. An assessment of elearning readiness at Open University Malaysia. International Conference on Computers in Education. 2004: 1017-22.

7. DehghanTarzjani MH, Alishiri N. E-learning Readiness Assessment in Alborz University of Medical Sciences. Alborz Univ Med J. 2017; 6(3): 179-86. [In Persian]

8. Mehdizadeh F, Mehdizadeh H, Sarmadi M, Azizi M, Allaei M. A study on electronic learning readiness of faculty members of western Iran's medical universities. J Ilam Univ Med Sci. 19(4): 62-69; 2012. [In Persian]

9. Ghanbari Khanghah A, Moghadasi Rostamnia T. Investigating knowledge, skill, and attitudes of faculty members and students of Gilan medical university on elearning. Bi-quarterly of center of studies and development of mediacal science teachoing. $\quad 2009 ; \quad 5(3): 108-10$. https://scholar.google.com/scholar?hl=en\&as_sdt $=0 \% 2 \mathrm{C} 5 \& \mathrm{q}=$ Ghanbari + Khanghah $+\mathrm{A} \% 2 \mathrm{C}+\mathrm{Mogh}$ adasi+Rostamnia+T.+Investigating+knowledge $\%$ $2 \mathrm{C}+$ skill\% $2 \mathrm{C}+$ and+attitudes+of +faculty+member s+and+students+of+Gilan+medical+university+o n+elearning. $+\mathrm{Bi}-$

quarterly+of+center+of+studies+and+developmen t+of+mediacal+science+teachoing. $+2009 \% 3 \mathrm{~B}+5$ \%283\%29\%3A108-10.\&btnG.

10. Abdollahi SM, Zamani BE, Ebrahimzadeh I, Zare H. Providing a Conceptual Model for Investigating Major Concerns and Inhibitors of Academic Participation by University Teachers in Virtual Education. Interdiscip j virtual learn med sci. 2010; 1(2): 2-9. [In Persian]

11. Gasaymeh A-MM. A study of faculty attitudes toward internet-based distance education: A survey of two Jordanian public universities. [dissertation]. Athens: The faculty of the College of Education of Ohio University; 2009.

12. Qashlagh OM, Mahdi Nejad V, Yaghoubi NM. Investigating Factors Affecting Faculty Members' Desire to Use E-Learning Systems. Interdiscip j virtual learn med sci. 2012; 2(3): 2838. [In Persian]

13. Fahami R, Zare H. An investigation of factors affecting accepting new technologies in distance education drawing on technology acceptance model (a case study of Esfahan Payame Noor 
University). J New Approach Educ Admin. 2013; 4(1): 67-79. [In Persian] 14. Zhang L, Wen H, Li D, Fu Z, Cui S. Elearning adoption intention and its key influence factors based on innovation adoption theory. Math Comput Model. 2010; 51(11-12): 1428-32.

15. Mishra S, Panda S. Development and factor analysis of an instrument to measure faculty attitude towards e-learning. Asian J Distance Educ. 2007; 5(1): 27-33.

16. Latifnejad Roudsari R, Hosseini BL. Measuring students' knowledge and attitude towards E-learning in Mashhad University of Medical Sciences (MUMS). Iran J Med Educ. 2011; 10(4): 364-73. [In Persian]

17. Zamani BE, Babadi Akashe Z, Soleimani N. Studying the Levels Using It by Faculty Members of Governmental Universities of Isfahan Province According to the Concerned Based Adoption Model: a comparative investigation. Iran J Inform process Manag. 2011; 26(3): 571-93.

18. Rezaei Raad M. Evaluation Of Payam Noor University Professors' Readiness To Use ELearning. Res Curricul Plan. 2013; 9(8): 110-16. [In Persian]

19. Sheikhain a, AliAbadi k, Roein 1, Hooshmandja m. Feasibility study of e-Learning project at Lorestan university of medical sciences from the viewpoint of faculty members, students, managers and executive staff in 2012-13. Yafte. 2015; 16(4): 5-17. [In Persian]

20. Darabiamin M, Yazdi Z, Darabi M, Fayezi SH, Bahrami E, Sarchami R. Infrastructure and Faculty Member Readiness for E-learning Implementation :The Case of Qazvin University of Medical Sciences. Iran J Med Educ. 2013; 13(9): 730-40. [In Persian]

21. bakhshi h, Farahi MM, Pooya A. Effect of Perceived Organizational Support on Organizational Commitment (Real Estate Registration Office in Mashhad). The second conference tools and techniques management; 2016. [In Persian]

22. Bates T, Poole G. Effective teaching with technology in higher education: Foundations for success. The University of Michigan: JosseyBass; 2003.

23. Smith PJ, Murphy KL, Mahoney SE. Towards identifying factors underlying readiness for online learning: An exploratory study. Distance educ. 2003; 24(1): 57-67.
24. Mehrdad N, Hooshmand bahabadi A, Yaghoobi N, Aalaa M, Sanjari M, Zolfaghari M. Evaluation of perceived satisfaction, usefulness and efficiency of virtual workshops from the perspective of faculty members and postgraduate students of Tehran University of Medical Sciences. J Med Educ Dev. 2015; 8(18): 125-36. [In Persian]

25. Allen NJ, Meyer JP. The measurement and antecedents of affective, continuance and normative commitment to the organization. J Occup Psychol. 1990; 63(1): 1-18.

26. Arshadi N. The relationships of perceived organizational support (POS) with organizational commitment, in-role performance, and turnover intention: Mediating role of felt obligation. Procedia Soc Behav Sci. 2011; 30: 1103-108.

27. Panaccio A, Vandenberghe C. Perceived organizational support, organizational commitment and psychological well-being: A longitudinal study. J Vocat Behav. 2009; 75(2): 224-36.

28. DeConinck JB, Johnson JT. The effects of perceived supervisor support, perceived organizational support, and organizational justice on turnover among salespeople. Pers Sell Sales Manag. 2009; 29(4): 333-50.

29. Shakerinia I, Nabavi S. The relationship between job satisfaction and the ercieved organizational support with organizational commitment in the staffs of police station of Giulan Province. police manag stud. 2010; 5(4): 608-24. [In Persian]

30. Poursoltani Zarandi H, Aghaei N, Asgari B. Relationship Perceived Organizational Support with Organizational Commitment among Staff. Sport Manag Stud. 2016; 8(35): 183-198. [In Persian]

31. Omidinia S, Masrom M, Selamat H. Review of e-learning and ICT infrastructure in developing countries (Case study of Iran). Am J Econ Busin Admin. 2011; 3(1): 120-25.

32. Murphy C, Greenwood L. Effective integration of information and communications technology in teacher education. J Inform Technol Teach Educ. 1998; 7(3): 413-29.

33. Bahadorani M, Yamani N. Assessment of knowledge, attitude and computer skills of the faculty members of Isfahan University of Medical Sciences in regard to the application of computer 
and information technolog. Iran $\mathrm{J}$ Med Educ. 2002; 2(1): 11-18. [In Persian]

34. Momeni Rad A, Aliabadi Kh. Quality assurance of e-learning by using electronic learning standards. Educ Strategy Med Sci. 2010; 3(3): 87-92. [In Persian] 